Canadian University Music Review

Revue de musique des universités canadiennes

\title{
The Social Interpretation of Modern Jazz
}

\section{Alan Lewis}

Numéro 2, 1981

URI : https://id.erudit.org/iderudit/1013748ar

DOI : https://doi.org/10.7202/1013748ar

Aller au sommaire du numéro

Éditeur(s)

Canadian University Music Society / Société de musique des universités

canadiennes

ISSN

0710-0353 (imprimé)

2291-2436 (numérique)

Découvrir la revue

Citer cet article

Lewis, A. (1981). The Social Interpretation of Modern Jazz. Canadian University Music Review / Revue de musique des universités canadiennes, (2), 138-165.

https://doi.org/10.7202/1013748ar

All Rights Reserved (C Canadian University Music Society / Société de musique des universités canadiennes, 1981
Ce document est protégé par la loi sur le droit d'auteur. L'utilisation des services d’Érudit (y compris la reproduction) est assujettie à sa politique d'utilisation que vous pouvez consulter en ligne.

https://apropos.erudit.org/fr/usagers/politique-dutilisation/ 


\title{
THE SOCIAL INTERPRETATION OF MODERN JAZZ
}

\author{
Alan Lewis
}

\section{Introduction ${ }^{1}$}

The history of jazz, unlike that of classical music, has always tended to be viewed in social as well as musical terms. Although its exact origins and earliest development are still unclear, jazz emerged as the folk art of a specific group of people, American Negroes, whose segregated social situation produced distinctive cultural patterns. In its popular commercialized forms of Dixieland and swing, the evolution of jazz seems obviously related to broad social changes associated with the development of mass consumption, mass media, and mass entertainment. The rapid changes in jazz musical styles are clearly related to changes in entertainment venues, recording technology, and the processes of commercial organization surrounding entertainment music. After all, popular music was - and is - a commodity and has to be in tune with the times if it is to be saleable on a large scale. Since the 1940s, the more esoteric traditions of jazz have evolved from an increasingly self-conscious high-art development of the original folk music traditions and elements, elaborated particularly in reaction against the pressures of commercialization and white imitation. As part of this artistic development, jazz evolved as a black instrumental music with instrumental virtuosity in improvisation at its core. The rapidly changing character of the American black community, particularly the shift from an agrarian to an industrial basis, transformed the conditions of production and reception of this music and interacted with the processes of commercialization and the musicians' attempts to escape commercialism.

The intensification of the 1950s civil rights movement and the ghetto riots and broader radicalization of the 1960 s have 
left their marks on the social interpretation of jazz. Three works in particular stand out as sociologically sophisticated attempts to connect the musical evolution of jazz with changes in racial relations and black political and cultural consciousness. Blues People by LeRoi Jones, the black poet and writer, appeared in 1963. Using a social anthropological perspective, Jones analyzes the way the post-Emancipation exclusion of the American black from the social mainstream produced a cultural tradition resistant to assimilation, even though major elements of the dominant white culture are borrowed and used in producing that cultural synthesis. Part of this novel cultural tradition has its roots in Africa and part in American experience, but it is entirely black, and not simply derivative of white American or European traditions. Black music - particularly jazz - clearly demonstrates the construction of a distinctive black culture which fuses African and European elements.

In 1970 a series of essays entitled Black Nationalism and the Revolution in Music appeared, written by Frank Kofsky, a white historian and jazz critic. Kofsky argued that the American black's status as a major part of the industrial reserve army, ${ }^{2}$ separated from the rest of the working class by special racist forms of exploitation and oppression, perpetuated a specific sense of national oppression on the part of blacks. This nationalism has had a long history, but is episodic in appearance because of the overwhelming power of white domination. However, black nationalism had grown continuously since the Second World War and ultimately exploded in the ghetto riots and black power movements of the 1960s. Black jazz musicians during this period were acutely aware of the cultural oppression of their people because of their own intense struggle for survival in an extremely competitive and exploitative commercialized field of music. Hence they were either in the vanguard or expressed clearly in their music the nationalism which was more slowly crystallizing in the consciousness of the broader community of American blacks.

A year later, Ben Sidran's Black Talk (1971) appeared. In many respects this work recapitulated Jones's analysis, using McLuhan's distinction between oral and literate cultures to specify the characteristics of the culture of blacks in America. Sidran sees black music as a developed expression of a more general oral foundation of black culture. For Sidran, black culture is founded on oral modes of communication and has 
produced advanced faculties of vocal expression and aural perception. Oral cultures are based on the spoken word and its oral derivatives, that is, musical representation of basic vocalizations. In contrast, literate cultures are founded upon visual and printed signals, which operate as a distancing and abstracting medium of communication. Hence oral communication is free from intervention of a medium while literary communication is dependent upon an intervening signal in space, such as printed words, stone inscriptions, punched cards, or pictures. Major consequences in psychological make-up, modes of emotional expression, and the organization of social relations are held to derive from these two basic approaches to perception and organization of information. ${ }^{3}$ In oral cultures music is of central importance ${ }^{4}$ - and in the case of American blacks it has been the only possible outlet of cultural expression. Consequently, according to Sidran, black musicians have a very special status within the black community; as virtuosos of the oral cultural tradition they have been in the vanguard of black cultural expression, articulating changes in mood and perception in advance of the bulk of the black community.

Despite their differing theoretical bases, these studies converge in their analysis of the relation between jazz and black social and political consciousness. Clearly, it is the view of these writers that since the 1940s black jazz musicians have been in the vanguard of the American black's growing ethnic assertiveness or nationalism, and that this has been expressed in the styles of music which have characterized jazz. Although there is considerable truth in this perspective, it is limited and misses a basic dynamic in the history of jazz.

\section{Jazz and Black Political Consciousness}

The arguments of Jones, Kofsky, and Sidran on the relationship between modern jazz and black political consciousness are threefold. First, jazz musicians as black Americans, suffer gross discriminatory practices in the music business and, with very rare exceptions, experience extreme hardship in the pursuit of their vocation. Secondly, not only do jazz musicians suffer discrimination in salaries, contracts, working conditions, the availability of studio session work, media work, and the best touring circuits, they are also consistently denied credit for their own music. While black musicians have created a music lauded elsewhere as America's major cultural product, jazz has 
been treated as a minor entertainment music and largely relegated to taverns in its native land. Where it is recognized, it is most often identified with white vulgarized and commercialized forms produced by white musicians who modify it to make it more acceptable to white audience taste and enjoy considerable financial success in consequence. Thirdly, in response to these circumstances, black jazz musicians since the 1940s have developed a music which is increasingly assertive of its ethnic roots and singularity. Three phases of jazz history exemplify the development of growing black pride - the bebop innovations of the early 1940s, the hard bop and soul or funk movements in the 1950s jazz, and the new wave jazz of the late 1950s and 1960s. Each set of musical changes corresponded with changes in the political and social characteristics of the black community and its relationship with the dominant white social order.

Until the Second World War blacks had little power vis-àvis whites and most blacks were fatalistic about chances for meaningful change. They did not control enough resources desired by whites to be able to bargain effectively. Nor could they coerce whites into making changes. They had nothing to offer to, or withold from, whites other than their labor. But blacks were kept too close to the minimal subsistance level to use their labor power as an effective lever for change. They were forced to rely upon persuasion as a tactic. The NAACP5 engaged in lobbying and litigation, while the Urban League ${ }^{6}$ used education and persuasion. Not until the outbreak of World War II were blacks provided with a bargaining lever, since the United States government needed to mobilize all of its internal strength to combat the Axis powers. Black noncooperation with, or active hindrance of, the war effort was threatening enough to coerce white compliance with some black demands, such as creation of the Fair Employment Practices Commission and some desegregation of the armed forces.

The willingness of blacks to threaten noncooperation with the war effort was itself rooted in the political and social experiences of the thirties. Ultimately Roosevelt's New Deal had failed; government power did not change hands, nor did the economic structure of America open significantly to allow blacks occupational mobility and economic advancement. Rather, the the New Deal seemed to salvage the pre-Depression economic structure with the large corporations emerging practically unscathed. It was, in fact, the "forgotten man," the average 
lower-class American, who benefited least, and in particular the black American who had to bear the added burden of racial discrimination and who remained fixed to the lowest rung on the socio-economic ladder. The Second World War with its begrudging integration of industries serving government contracts and its fight against racist Fascism on the Western Front (albeit combined with racist anti-Japanese propaganda on the Pacific Front) opened up the possibility for black economic and political leverage. While the civil rights politics of the largely white U.S. Communist Party disappeared with the Party's all-out support of the war effort, black leaders such as A. Phillips Randolph and organizations such as $\mathrm{CORE}^{7}$ adopted militant, non-violent methods of protest against discrimination and segregation. Although executive action imposed desegregation of defence industries and opened up jobs with improved economic status, racism persisted on a massive scale. At the height of the war, in 1943, a bloody race riot occurred in Detroit in which thirty-four people died. Earlier in the same year, upgrading of black shipyard workers in Mobile, Alabama triggered a riot requiring troops for its suppression.

The Depression had hit agriculture even more severly than it affected industry, causing a major migration from rural to urban areas. This was reinforced by the mechanization of agriculture and the industrial boom arising from the war effort. After 1929 blacks came to the cities in ever-increasing numbers. The Depression had hit blacks very hard and this was as true in their relation to the entertainment industry as everywhere else. "Race" recordings designed specifically for black record buyers disappeared from the market in the early 1930s while racial criteria for job qualifications intensified in radio stations, ballrooms, dance halls, and theaters. At the same time, touring circuits for musicians and other entertainers were increasingly segregated as the more lucrative were monopolized by white performers (see Jones 1963:177-80). The most vital regions of jazz creativity moved from New York and Chicago to Kansas City and the Southwest. In Kansas City the Pendergast machine supported a freewheeling, dance-hall-saturated city with a large black population where urban jazz traditions and rural blues mingled. A fusion occurred producing the Bennie MotenCount Basie band blues and a new style of shouting blues singers. Both developments were associated with the rise to 
prominence of a new generation of sophisticated instrumentalists such as Roy Eldridge and Lester Young.

However, the position of the black jazz musician was undergoing considerable and rather peculiar changes. As jazz expanded in the later twenties and became incorporated into a broader entertainment industry, it attracted musicians from more respectable, urban middle-class origins. The Depression paradoxically reinforced this because only those musicians with the training and versatility to perform in pit orchestras and a variety of musical contexts could survive as professional musicians playing with jazz bands. A greater level of musical training combined with a shift in emphasis toward solo performance to establish individual instrumental virtuosity as the essential criterion of musical competence. But the Depression had ghettoized jazz and forced musicians with higher training and, to some extent, more middle-class background, to perform almost exclusively for lower-class black audiences.

The 1930s also witnessed a new phase in the global acceptance of jazz. In its native land jazz was received with great hostility by critics and bodies associated with the fine arts. ${ }^{8}$ However, even in the 1920s Europe had proven to be not only as open as America in its acceptance of jazz as a popular entertainment music, but far more welcoming in terms of elite approbation. European classical musicians acclaimed (and misunderstood) ragtime and early jazz, while groups of middleclass people formed "hot clubs" and "rhythm clubs" of recordcollecting cognoscenti. Ultimately France provided the first major jazz critics who attempted to develop aesthetic systems for interpreting and defining the music and evaluating its performers and their works. ${ }^{9}$ Although these developments had little direct impact on the white American reception of jazz, there was sufficient transatlantic movement by jazz musicians for the different form of jazz appreciation in Europe to filter through the American scene and fuel the jazz musician's increasing sense of professionalism.

The final set of circumstances throwing the jazz musician into a state of uncertainty was the impact of commercial "swing," the jazz-derived popular dance music which swept the popular music scene in the thirties and early forties. Fletcher Henderson's arrangements for Benny Goodman and Jimmy Lunceford's work for the Dorsey brothers launched a new dance fad and band style. The commercialization of a black jazz style, 
of course, ensconced white bands and their leaders in economically dominant positions. Their rapid commercial success quickly formularized the musical style and imposed a series of rigidly stereotyped demands on musicians throughout the entertainment field. It is likely that media penetration into the black community increased with black urban migration, and so forced black bands themselves to play a certain proportion of the most popular tunes. Concomitantly with these developments the jam session emerged - after-hours sessions where musicians and a few close associates gathered to demonstrate virtuoso improvisational capacities through competitive performance, testing both stamina and imagination. The jam session was symptomatic of a period when the consolidation of jazz as an improvisor's art began to clash with the dance band and similar entertainment functions which economically sustained it.

The bop musicians of the early 1940 s built on the musical innovations of the $1930 \mathrm{~s}$ and made explicit the perspective embodied in the jam session. ${ }^{10}$ Jazz, the performers'art, was no mere entertainment music but an art to be ranked with the rest of the high arts:

The music of Charlie Parker and Dizzy Gillespie represented a way for jazz to continue, but that way was not just a matter of new devices; it also had to do with a change in even the function of the music. Parker's work implied that jazz could no longer be thought of only as an energetic background for the barroom, as a kind of vaudeville, as a vehicle for dancers. From now on it was somehow a music to be listened to (Williams 1973: 106).

In rejecting the entertainer image of the jazz musician the boppers also rejected the restricted and stereotyped roles available to blacks in American society.

Corresponding to these changes in the self-image of the jazz musician were a number of radical changes in musical style. In the words of James Collier:

Where tempos had been medium, they were now fast or slow. Where the first, third, fifth and seventh notes of the scale had been stressed, now the second and fourth were played up. Where the first and third beats of a measure had been accentuated, now it was the second and fourth. Where pairs of notes had been played extremely unevenly, now 
they were played almost equally. Where choirs of instruments had harmonized, now they were played in unison. Bop was, in the exact sense of the word a musical revolution. These men turned the jazz world upside down and sat on the top, thumbing their noses at their elders falling off the other side (Collier 1978: 360-61).

The bop musician's novel and aggressive assertion of his artistic status, and his uncompromising pursuit of a complex style of jazz, mirrored the new level of black assertiveness in the war and post-war period. Important gains had been made in jobs and income during the war, but these were now threatened by post-war economic slowdown. For most blacks, especially those in the northern cities, the key question was one of safeguarding their newly achieved economic and social status. As early as 1945 NAACP lawyers began planning a legal assault on the segregation system in the South. CORE, favoring non-violent direct action, began to launch freedom rides throughout the South in 1947 to test the enforcement of a Supreme Court decision outlawing segregation on interstate buses. At the same time the Nation of Islam or Black Muslims, founded in 1930 and scarcely growing for fifteen years, began to increase in numbers after the war. From 1945 with four temples and nine thousand members they increased to fifteen temples in 1955 and to thirty temples in 1959. While CORE and the NAACP were middleclass organizations directing their attacks against Southern segregation, the Muslims were strongest among working-class blacks residing in the urban areas of the North (see Geschwender 1978: 201-18). Both the Nation of Islam and other more orthodox Islamic groups gained adherents from the jazz community in the late 1940 s and early 1950 s.

Although the post-war period brought some reversals to the occupational and economic advances of American blacks, these were soon compensated for by the economic boom accompanying the cold war and the Korean War. The Truman administration was more explicit in its support for civil rights than its predecessor had been, and a real measure of desegregation in government services and the armed forces occurred. These developments reinforced the steady shift of blacks from the rural south to the cities of the east, midwest, and far west. Outside the United States, independence movements in Asia and Africa had begun to erode European colonial domination. All these factors appeared to have heightened the confidence 
and increased the expectations of black Americans. The NAACP maintained its steady pressures for legal reform, while CORE and the Urban League undertook educational campaigns and various pressure-group actions to further black advancement. After 1955 these organizations were joined by Martin Luther King's SCLC ${ }^{11}$ which became a major coordinator of direct action throughout the South. At the same time the Black Muslims continued to expand.

These various changes were reflected in diverse ways in the jazz scene. By the late forties several jazz musicians had adopted the Islamic faith and had publicly taken Muslim names. In the fifties jazz musicians began to visit Africa, studying African music and even playing with tribal drummers. References to Africa appeared with increasing frequency in the fifties, beginning with Miles Davis's 1954 recording of Sonny Rollins's composition Airegin (i.e., Nigeria spelled backwards). A blues turn was a marked feature of 1950s hard bop, the predominant black jazz style evolving out of bebop. Hard bop emphasized hard-driving, fiery, melodically complex improvisation and heavy-weight, raw-textured tone colors which were in striking contrast to the characteristics of the West Coast post-bop style favored by white jazz musicians.

The Northeastern cities such as Detroit, New York, and Philadelphia which were the centers of hard bop were also major centers for the production of black popular vocal music, known by its trade name as rhythm and blues. The latter was a fusion of several musical streams: 1930s band blues originating in the Kansas City region and developed by Louis Jordan, black gospel music, and various intermixtures of black and white rural music. A significant number of black jazz musicians, particularly saxophonists, began their careers playing in rhythm and blues bands and many seemed to bring this experience into the jazz they played in the 1950s. In this decade, the use of blues chord progressions, pioneered in Miles Davis's Walkin' session of 1954, became a distinctive style within hard bop. Blues- and gospel-tinged compositions and arrangements became the hallmark of Art Blakey's groups, the Adderley brothers, much of Mingus's work, and was especially marked in keyboard players influenced by Horace Silver such as Ray Bryant, Les McCann, Mal Waldron, Bobby Timmons, and Jimmy Smith (see Kofsky 1970: 9-97 and Wellburn 1971). 
All these developments in the music seem to be symptomatic of a broader change of attitude, an increase in self-confidence and ethnic pride within the black community at large. The major domestic tactic adopted by the Eisenhower administration to sustain America's image and self-adopted role as leader of the "Free World" was the support of the desegregation measure ruled by the Supreme Court in April 1954. The resulting Federal intervention against Southern states which attempted to halt desegregation sustained the black community's optimism and rising expectations. Between 1956 and 1960 black protest declined until the February 1960 Greensboro, North Carolina sit-ins ushered in a new phase of militance. In the early years of the new decade sit-ins became a major and effective tactic because they disrupted business and caused a loss of profits. As the sit-in tactic spread through the South it met increasingly large-scale and violent white resistance. Publicity accompanying white violence stimulated support from the liberal white public and unified the black community North and South. Northern support was expressed through picketting and boycotting northern affiliates of chain stores where there were sit-ins. CORE entered the Deep South for the first time and helped to organize and conduct sit-ins. Throughout the early 1960s the civil rights movement changed rapidly. Tactics escalated in level of militancy. Boycotts and sit-ins were soon supplemented by mass marches, blocked streets, impeded construction vehicles, and voter registration drives. While the NAACP continued its litigation and lobbying activities CORE, SNCC,12 and SCLC specialized in non-violent direct action. Rising expectations, hardening anger at white resistance, and organizational rivalry all contributed to increasing militancy as each organization attempted to outdo the others (see Geschwender 1978: 222-38 and Allen 1970).

The movement achieved limited success. The white liberal public saw non-violent blacks making reasonable demands and being brutalized for their efforts. This aroused sympathetic support, and the federal government was pressured into intervening. Local businessmen urged concessions when disruption hurt tourism and drove away new industry. The civil rights movement broadened its base from its initial middle-class composition as victories raised aspirations and attracted working-class blacks. Dissatisfaction with the rate of change increased concomitantly with the growing belief that change 
was possible. Increasing numbers of less well-disciplined participants demanded more and faster change, turned toward more militant tactics, and reduced their commitment to nonviolence.

This same period, the 1960s, was an especially fertile period for changes in the sound of jazz. Apart from the fact that a number of 1950s-era innovators reached their creative peaks in the following decade (much as many of the pre-bop musicians attained creative peaks in the 1940s and 1950s), there was a proliferation of new approaches to jazz creation. Collective improvisation, which had fallen into disuse with the demise of Dixieland, was revived by Coleman, Coltrane, Mingus, Sun Ra, and Cecil Taylor. Miles Davis and Coltrane explored improvisatory methods based on modal forms rather than on harmonically founded chord progressions. New instruments such as the fluegelhorn, flute, soprano saxophone, and auxiliary percussion broadened the spectrum of jazz timbres and textures. Toward the end of the decade, non-European instruments were being used with greater frequency than ever before, and electronic instruments, amplification, and electronic devices which altered the sound of conventional instruments became increasingly common. In addition to using new instruments, old instruments were played in new ways: exploitation of the high register of trumpets and saxophones became common; saxophonists cultivated new techniques to drastically bend their pitch and tone, sometimes playing several notes simultaneously, and at the same time producing a huge assortment of shrieks, squawks, and wails. Instrumental proficiency increased as guitarists, pianists, bassists, and drummers in particular generally played faster and more precisely. New instrumentation and combo organization were explored: the piano was absent from many recordings by Coleman, Shepp, Ayler, and Rivers; a variety of duet forms were explored; several pianists recorded solo albums without the usual accompaniment of bass and drums; rhythm sections increasingly came to the forefront in ways previously assigned to reed and brass soloists. Compositional forms, melodic styles, and improvisation altered radically as well. During the 1960s fewer compositions fit the traditional twelvebar blues and thirty-two-bar AABA popular-song chord progressions. Rather, tunes were more expansive, often modal, floating, often simpler and smoother, with less pronounced syncopation and fewer notes than bop compositions. Sustained 
notes and silences often became just as important as rapid-fire runs had been to bop and hard bop. While tunes were becoming simpler and smoother, rhythm-section activity became more complex and turbulent, sometimes operating without strict meter or constant tempo. Much improvisation was based on far fewer chords than had typified bop and hard bop compositions, and for many performances the player invented his own harmonies while improvising instead of presetting them beforehand. In place of bebop's complex chord progressions and elaborately syncopated melodies, 1960s jazz saw an emphasis on colorful sounds and provocative rhythms, the generation of moods and textures, and the exploration of sound for sound's sake rather than for the sake of melody, harmony, or swing feeling. ${ }^{13}$

The jazz characterized by these changes originated particularly with the work of Ornette Coleman, John Coltrane, and, despite his verbal hostility to much of the avant-garde, Miles Davis. The avant-garde jazz (known as the "New Thing") movement of the 1960s, like the bebop movement of the early 1940s, was infused with strong ideological components. In contrast to the earlier movement, however, the New Thing experimentalists could draw upon more definite political elements with which to articulate the socio-political aspects of their aesthetic principles. The rise of active liberation struggles to decolonize the Third World now often included in their targets the United States as an ally of colonial powers; the radicalization of the civil rights movements, and particularly the definition of the civil rights issue, shifted from Southern desegregation to combatting white racism wherever it might be found; the eruption of the Chinese Cultural Revolution provided an apparent break with the grey totalitarian tradition of Stalinism; and the anti-imperialist rhetoric of the opposition to America's Vietnam involvement escalated. All these developments provided a rich source of social and political images and conceptions which the bebop movement lacked, operating as it did in the consensual atmosphere imposed by the Second World War.

Again in contrast to the bebop movement the New Thing musicians had articulate black critics in LeRoi Jones and A.B. Spellman, who drew the connections between shifts in music and broader changes in black consciousness and racial relations in a very effective way (see Jones 1967 and Spellman 
1967). ${ }^{14}$ Among the musicians, the tenor saxophonist Archie Shepp was the most insistent in connecting the style and substance of the new music with broader social changes. ${ }^{15}$ However, the dominant tone of the new wave musicians' account of their musical aims and practice might be characterized as a form of spiritualism, even a form of black hippie ethics, rather than as a primarily political ideology. Like the hippies, the New Thing players espoused an ideology which emphasized both individualism and collectivism equally. This perspective is captured perfectly in Roswell Rudd's statement, "I was trying to get the music out of each guy in a kind of democratic or communal way so everybody could unload this stuff but with a balanced and communal form" (quoted in Collier 1978: 475). The New Thing practitioners shared other features with the hippies: an interest in - for John Coltrane an obsession with oriental mysticism and non-Christian religion, particularly their contemplative and occult features; an emphasis on nonrational and non-verbal communication which produce heightened states of empathy; an antagonism toward formal and articulated criteria of judgment emphasizing technical training and skill; and an emphasis on individual freedom of expression or "doing one's thing" unhindered by formal discipline.

It seems quite clear that the ghetto riots and general social turmoil of the 1960s politicized and molded the self-consciousness of the black jazz musician. Yet the ambiguities and paradoxes of the jazz musician's status in America, which had begun to emerge in the 1930s, were reproduced in new forms. While the bebop innovations had at first caused a great deal of controversy among jazz musicians and critics, these had rapidly waned as bop itself moderated and many swing-era musicians found themselves able to work with the new genre and its practitioners. The New Thing movement likewise ushered in a period of bitter disputes which cut deeply into the ranks of jazz musicians. Not only white critics but black and white musicians as diverse as Ray Bryant and Charles Mingus came to condemn much of the New Thing as a fraudulent cover for inept and undisciplined individuals searching for a quick route to economic success. Much of the new music was also criticized for its abstractness and lack of emotional accessibility. Essentially these criticisms display a contradiction already embodied in the jazz tradition's ambivalence toward solo instrumental virtuosity as against the 
need for greater overt audience response and involvement than is found in classical concert music. ${ }^{16}$

The concern for the audience expressed in some jazz musicians' response to the New Thing must also be related to the massive popularity of rock music which occurred at the same time as Coleman, Shepp, Coltrane, Ayler and others became prominent in jazz. Although the evolution of post-bop jazz permitted a great deal of mutual collaboration between swing era and modern stylists, with some mutual modifications of style into a broad "mainstream," few established swing musicians made a full transition and became accomplished bop players. Consequently many musicians in their prime years were performing stylistically dated music and found their performing opportunities constricted as a result. In the 1960s the established musicians in hard bop found themselves besieged on two fronts: the New Thing stylists appeared to be capturing critical attention while a new, revitalized rock music was capturing the white college audience which had formed a significant proportion of the jazz audience. The combination of these processes created a pervasive anomia - a sense of loss of boundaries and standards. In rock it appeared that indifferent musicians could make fortunes while in the New Thing a new cohort of jazz musicians with questionable technical capabilities (in hard bop terms) were launched on their musical careers without having to "pay the dues" (see Sidran 1971: 154-55). Ultimately the boundaries of jazz itself seemed to disappear altogether as rock groups experimented with elements of jazz, Miles Davis and others experimented with electronic orchestration characteristic of rock, and New Thing musical styles were assimilated into the experiments of post-classical academic musicians. As had happened before, a major stylistic revolution originating primarily in the playing of a cohort of black jazz musicians came to be a vital influence on a variety of musical endeavors often associated with white musicians and audiences.

\section{Jazz and Modernism}

The three works drawn upon to develop the forgoing account of the development of modern jazz in its socio-political context all bear the marks of the high expectations produced by the social polarization of the 1960s. All three authors stress the parallels, congruences, and convergences between growing political militancy in the black community and innovations 
in jazz since the 1940s. However, reading changes in jazz styles as artistic expressions of a growing black nationalism overlooks the real complexity of the social location of jazz in American society and fails to account for some key factors contributing to the evolution of modern jazz.

Jazz, like rock and roll, is a music which has evolved almost entirely within the era of the mass production and mass consumption of culture within advanced capitalist societies. ${ }^{17}$ Consequently the development of jazz is very much molded by twentieth-century conditions of cultural expression and transmission. Jazz also shares with rock and roll the experience of becoming rapidly diffused as a popular music throughout the advanced industrial world. This latter characteristic suggests that these musical forms resonate with the emotional and perceptual experiences generated by modern living. Jazz, then, is embedded in a broader configuration of social processes which are likely to be expressed in its evolution as much as is the particular cultural experience of its primary creators who, of course, also share in the experience of modernism. The location of jazz in the culture of modernism should be explored not as an exclusive alternative to the socio-political interpretations of Jones, Kofsky, and Sidran, but as an equally important dimension which is underemphasized in their works. Such an analysis can be developed first by looking at the evolution of jazz as a musical tradition, and then comparing that evolution with the development of the arts in the western world.

The classical music critic Henry Pleasants has argued that the evolution of jazz has paralleled that of Western classical music in an accelerated manner (see Pleasants 1969). Until the 1930s, when the emergence of harmonically advanced players like Coleman Hawkins, Roy Eldridge, and Lester Young laid the foundations for the bebop revolution, jazz improvisation focused on the elaboration of melodic lines which approximated eighteenth-century classical melodies in their complexity. The bebop revolution moved jazz to harmonically focused improvisation resembling the expansion of permissible notes and harmonies which arose with chromaticism in nineteenth-century European classical music (see Harrison 1976: 94-107). In the process of its development, bop divorced jazz from its earlier associations with the popular song and with the function of social dancing, and became an art form which, like the other arts in contemporary western society, is largely isolated from 
related social functions. The rise of avant-garde jazz from the late 1950s on intensified the art-music character of jazz. The New Thing was a broad-scale onslaught on the received forms of the bop tradition and attempted to demolish wholesale the inherited compositional forms of the blues and popular song, to break from constant tempo, and to improvise without melodic or harmonic restraints. These characteristics of the New Thing had many parallels with avant-garde post-classical European art music which explored sounds, textures, and moods without recognizable melodies and harmonies, and adopted accidental constructions and electronically mediated forms of composition and performance.

Associated with these trends in jazz were fundamental changes in the self-conception of the musician and the relationships between him and his audience. Prior to the 1940s the jazz musician's status was unambiguously that of an entertainer, or creator of popular music in close and sympathetic relationship with popular-song and dance fashions. Only outside America did a few European critics and composers see jazz as an art form, and even then largely as a primitive or folk art, the spontaneous expression of unschooled musicians of natural genius whose rich creativity was untrammelled by formal, aesthetic self-consciousness. In their revolt against the restrictions of a commercially stereotyped big-band dance music, the bop musicians also sought to change the stereotyped images of jazz musicians as entertainers or exotic primitives. In their stage demeanor the bop players were aloof and distant where earlier musicians had been expansively open in their cultivation of audience involvement (see Route 1971: 125-26). The core of the modern jazz performance, improvisation over a series of chord changes, became an esoteric enterprise hidden from all but the most committed listener. Like modern literature at the turn of the century, which dropped the notion of the "common reader," the jazz musician came to despise the "square." Jazz performance became a mystery, involving an "unperformed cantus firmus" - the popular tune with its chord changes so modified as to be unrecognizable to the casual listener. The titles of these compositions were themselves invested with cultic significance, full of double entendres, puns, and in-jokes known only to the initiated (see Tirro 1967).

Lacking the easier identification with the musician's practice through the link of memorable melody or social dancing, 
the technical virtuosity required by the bebop innovations in harmony and rhythm became the only general link with the audience:

Trumpets were played higher than they had ever before been played. ... Saxophones were made to yield a thousand or so notes a measure, along with the uncouth grunts and squeals at the extremes of the range. Double-bass players developed a dexterity beyond the wildest imaginings of any symphony orchestra bassist, and drummers opened up an entirely new world of rhythmic and percussive variety. Pianists adopted a driving velocity modeled on the symptoms of Bud Powell's infatuations with Parker.... Vibraharp and guitar virtuosity added to the fun (Pleasants 1969: 144).

Such virtuosity, however, tended to feed stylistic fragmentation as subsequent generations of musicians chose from the innovations and discoveries of the boppers only those devices which appealed to them and which might be useful in generating a following as an "original" player. This stylistic fragmentation was intensified, of course, by the greater efficacy of electronic mass media which communicated changes in musical fashion through recordings at an ever-increasing pace.

Rhetorically the bop musicians asserted that their music was serious art. They were not unlettered primitives but musically sophisticated virtuosos who were fully cognisant of the nature and significance of Bartók, Stravinsky, and other modern classical composers. As practitioners of a serious music they demanded the consideration accorded to artists in other fields.

Like avant-garde artists elsewhere the bop musician

formed an elite of his own - a model of any exclusive grouping in any society anywhere, idealistic, self-satisfied and disdainful of the outside world, protecting itself against intrusion by constantly changing modes of expression and behavior. In this pattern the modern jazz musician has adopted the attitudes of the serious music establishment. The artist stands alone, and must be independent of the public. Only artists are qualified to pass judgment on fellow artists. The public is obliged to listen, to be respectful and to pay; the artist is not to please the public, for entertainment is beneath the true artist's calling. These romantic into modernist visions have been supported by 
jazz critics and have produced in jazz an accelerated history of the development of classical music (ibid.: 140).

Although modern jazz musicians' claims to be treated as artists have only been partially successful, there has been an increasing legitimation of jazz involving its separation from other varieties of popular music, and a decline in sweeping condemnations of it as being simply part of mass culture (see Leonard 1962 and Shepherd et al. 1977: 179-200). Associated with this rise in status has been the institutionalization of the role of the critic who mediates between the artist and his audience. In this development, as well as those outlined above, the evolution of jazz has followed that of the arts as a whole since the nineteenth century. Thus, in characterizing the literary avant-garde of the early twentieth century, Irving Howe could easily be describing the status of the jazz musician since 1940 when he writes:

Forming a kind of permanent if unacknowledged and disorganized opposition, the modernist writers and artists constitute a special caste within or at the margin of society, an avant garde marked by aggressive defensiveness, extreme self-consciousness, prophetic inclination and the stigmata of alienation (Howe 1967: 23).

This avant-garde, Howe notes, has its own community, Bohemia, which is both "an enclave of protection within a hostile society" and "a place from which to launch guerilla raids upon the bourgeois establishment, frequently upsetting but never quite threatening its security" (ibid.). Again the modern jazz musician's conception of his artistic practices are well captured by Howe's description of modern literary artists:

The avant garde abandons the useful fiction of the "common reader," it demands instead the devotions of a cult. The avant garde abandons the usual pieties toward received aesthetic assumptions; "no good poetry," writes Ezra Pound in what is almost a caricature of modernist dogma, "is ever written in a manner twenty years old." The avant garde scorns notions of "responsibility" toward the audience; it raises the question of whether the audience exists - of whether it should exist. The avant garde proclaims its faith in the self-sufficiency, the necessary irresponsibility, and thereby the ultimate salvation of art (ibid.: 23-24). 
It is no accident perhaps that LeRoi Jones, a modernistic literary practitioner himself, clearly perceived the common ground between modern jazz musicians and other modern artists. Jones argued that the

... artist and his fellow-traveller, the Bohemian, are usually regarded in this society as useless con-men and as such, are treated as enemies. The complete domination of American society by what Brooks Adams called the economic sensibility, discouraging completely any significant participation of the imaginative sensibility in the social, political, and economic affairs of the society is what has permitted this hatred of the artist by the "average American." This phenomenon has also caused the estrangement of the American artist from American society, and made the formal culture of the society (the diluted formalism of the academy) anemic and fraught with incompetence and unreality. It has also caused the high art of America to be called "the art of alienation." The analogy to the life of the Negro in America and his subsequent production of a high art which took its shape directly from the nature and meaning of his own alienation should be obvious. This consideration (dealt with consciously or instinctively) certainly reshaped certain crucial elements of the American art of the last two decades, and gave a deeply native reference to the direction of American Bohemianism, or the artist's life of the fifties (Jones 1963: 230-31).

That jazz became a terrain of avant-gardism before it was half a century old is scarcely surprising. The role of the individual in the development of jazz, as John Storm Roberts points out, has been of overriding importance:

Virtually all the major changes in jazz have been associated with a few individuals (though clearly they could not have wrought the changes single-handedly): Buddy Bolden, who appears to have provided a bridge between band marches and ragtime and band jazz; Jelly Roll Morton, in somewhat the same position; Armstrong, who introduced the era of jazz as a music for soloists; Coleman Hawkins and Lester Young, who helped turn jazz from a trumpeter's to a saxist's music; Charlie Parker and Dizzy Gillespie; Ornette Coleman and Cecil Taylor; and perhaps Archie Shepp (Roberts 1974: 216). ${ }^{18}$ 
Moreover, Roberts continues, jazz musicians "speak for a people whose major group experience has been a denial not so much of humanity as of individuality" (ibid.). By the mid-1920s jazz had emerged as an improvisational idiom whose key agent was the individual soloist. Hereafter compositions and arrangements were predominantly platforms or settings for the display of individual instrumental (and particularly in the 1930s and 1940 s vocal) virtuosity. At the heart of jazz, then, were two characteristics fundamental to artistic modernism; the emphasis on the unique creative potential of the individual artist - the cult of genius; and, an emphasis on the process of creation - improvisation - rather than an emphasis on its formal end product.

The general characteristics of modernism in the arts became significant in bop and all-pervasive in the New Thing music of the late 1950s onward. In the twentieth century the arts have lost that coherence which comes from a unifying set of principles focused on a particular form of artistic creation. In painting and the plastic arts the conventions of realism which attempted to center everything in the natural abilities of human sight have been abandoned. In literature the conventional narrative based upon the fixed sequence of a social career or the natural life cycle is outmoded. In modern jazz, particularly since the 1960s, the Afro-American song (the blues) and the Tin Pan Alley song is no longer the basic framework for arrangement, composition, or improvisation. In each of these instances the aim of the art prior to modernism was the production of aesthetic objects which were accessible to and expressive of essential and universal features of all humanity:

The convention of perspective, which is unique to European art and which was first established in the early Renaissance, centres everything on the eye of the beholder, on the specifically human eye. Pre-modern literature operated to sustain empathy and emotional involvement by appealing to the experiences of the "common reader." (Berger 1972: 16).

Pre-modern music, both popular and classical, is melodically based, its composers seeking memorable melodies and repeating them to ensure the listener's memory of them. Even in the elaboration and subjection of melodies to juxtaposition and development in a composition, repetition and regular return 
to the initial melodic ideas insured that the remembered strain was not easily lost. The Renaissance humanism which celebrated the active powers and senses of the human individual was, of course, the foundation of these artistic conventions. Each artistic domain, in the Renaissance perspective, was designed to cultivate, enhance, celebrate, and organize the active faculties of human reason, emotion, and imaginative perception.

Modernism developed in the arts as a reaction to both the exhaustion of humanistic conventions as guides to further creativity, and in response to the increasing sense of dislocation between humanism and the experience of modern living. Instead of basing its artistic conventions on some presumed set of naturally given universal human faculties, artistic modernism takes artistic conventions themselves as the terrain for creative exploration. For example, painting becomes preoccupied with texture, structure, and medium - breaking away from the problem of painting recognizable objects in a recognizable manner - exploring techniques for representing the intangible qualities of light, using paint itself as a subject for art, ultimately breaking away from the easel, and involving the artist's own person in painting. In classical music there occurs a gradual "emancipation of dissonance" as the harmonic vocabulary is enlarged to admit previously unacceptable discords. The resulting level of chromaticism in European classical harmony at the turn of the century required new formal principles as its basis. These organizing principles were partially provided by serialism but, ultimately, the very shift away from earlier conventions opened up a broad range of possibilities to be explored atonality, musique concrète, neoclassicism, electronic music all of which remold musical conventions without replacing them with a dominant organizing tradition.

Parallel processes, amounting to what Ortega y Gasset (1948) has called "inversion," occur throughout the arts where the conventions of the arts themselves become the essential object of manipulation and exploration rather than being the means to the representation of human realities. These processes bring with them an obsession with technique, abstraction from general human experience, and stylistic fragmentation. With the loss of a unifying set of principles of organization the modern artist questions "the right of the ordinary world to be considered more real than the fabricated world of play" (Lasch 1979: 161). The artist's feeling and imagination become 
established as the ultimate foundation of aesthetic practice. In the process both art and life come to be treated as fiction: the arbitrary imposition of meaning on otherwise meaningless experiences. In contrast to the Renaissance vision of art as a presentation of coherent and generally recognized truths, art becomes the field of pure intuition and imagination in a world which is seen as a shadow-play without substance. In modern art human experience rather than human perception is the foundation and focus of aesthetic practice.

In jazz, of course, the experience which is fundamental is the black experience. Herein lies a major difference between jazz and the other modern arts; the bulk of jazz musicians have been members of an oppressed and underprivileged group and not inhabitants of a deracinated, footloose Bohemia. However, the black population of America has been subject to extremely rapid urbanization and its associated social changes, including incorporation into a particular homogenized society where cultural differences are diminished by the power of the mass media and a very narrow political-ideological spectrum. Further, class and ethnic identity in America has always been evanescent and marginal in the face of the hegemonic ideology of liberal pluralism (see Allen 1970 and Jones 1972). Black collective identity, rooted largely in the black middle classes - caught between wanting the acceptance and rewards of white society while establishing and maintaining leadership and control over the black community - has shared this delicate dilemma in the extreme. Cultural nationalism could not easily be generated in a society characterized by a high degree of anti-intellectualism, an emphasis on and institutionalization of technical professionalism, and a consequent lack of an intelligentsia. All of this contrasts with the conditions producing the black intellectuals of the French African colonies who were to articulate visions of Negritude and African socialism (see Cook and Henderson 1969). American political and cultural conditions by contrast have provided very little in the way of symbolic resources for the American black community to articulate a communal identity. Jazz musicians have shared this weakness, adopting the Romantic tradition's conception of art and the artist in the 1940s and the "do your own thing" ethic of the hippies in the 1960s. Both aesthetic visions are variants of the general tendencies of modernism in the arts. 


\section{Conclusion}

It is apparent that jazz in some ways shares the evolution of modern art; that its aesthetic conventions have become disassociated from the human center of song and dance; that the exploration of new techniques and instruments has proceeded at an increasingly rapid pace; and that there has occurred an intensification of stylistic fragmentation which threatens to dissolve jazz as a musical idiom. Jazz also shares with modernism in the arts an intense individualism which is embodied in the cult of artistic genius and, increasingly, in the subjectivism which exhalts the artist's experience as the object-and-discipline whose expression subordinates all artistic conventions. While Jones, Kofsky, and Sidran correctly indicate some of the links between black collective consciousness and jazz, they overestimate the strength and autonomy of these connections. Consequently they overlook the parallels between the evolution of jazz and the other arts and the way these developments are related to a larger cultural and social configuration. 


\section{NOTES}

1. I am indebted to Frank Nutch and Deborah Van Wyck for their criticisms and stimulation in the course of writing this paper, and to John Shepherd for some useful comments on an earlier draft.

2. Since the First World War and the end of large-scale immigration, blacks in America have formed a labor pool to be drawn on for casual or shortterm employment, or used under emergency conditions such as war. Under these circumstances black workers tend to be found in the least skilled jobs with minimal prospects of long-term security let alone career advancement (see Peck 1968).

3. Sidran draws largely upon McLuhan (1962) for his analysis. McLuhan's work has inspired other researchers who have now documented and elaborated his ideas further (see Goody and Watt 1963, Ong 1967, and Ong 1969).

4. Useful summaries of the distinctive ways music is located in oral as opposed to literate cultures are found in Shepherd 1979 and Shepherd et al. 1977: $71-78$ \& 125-53.

5. The National Association for the Advancement of Colored People was founded in 1910 under the leadership of W.E.B. DuBois. The organization focused on litigation, legislation, and education to achieve social, political, and economic equality for blacks. Its most significant legal victories were the Supreme Court decisions protecting black franchise (1915), abolishing municipal housing segregation ordinances (1917), and declaring the illegality of school segregation (1954).

6. The National Urban League was created in 1910 with the combination of several groups that had been working on the urban problems of housing, employment, family disorganization, and juvenile delinquency. Its early actions were aimed at opening up new opportunities in industry to blacks and at assisting newly arrived migrants from the rural South in their adjustment to city life.

7. The Congress of Racial Equality was founded in Chicago by James Farmer who was much influenced by Ghandi's use of mass, peaceful, direct actions in protest against British rule in India. The organization's earliest efforts were directed toward desegregating public accommodations such as restaurants and mass transit facilities, using sit-ins and boycotts as major tactics. In the 1950s the organization increasingly focused on economic discrimination, again using direct action techniques such as picketting and boycotting places of employment in attempting to open up job opportunities for blacks. In 1961 CORE gained national and international attention as the major sponsor of the Freedom Rides into the Deep South, and quickly evolved into one of the most radical civil rights organizations.

8. A detailed investigation of the pre-Second World War reception of jazz by white society in America can be found in Berger 1947.

9. On the European reception of jazz generally see Oliver 1975. In France the Paris surrealists of the 1920s expressed an aesthetic affinity for jazz (see Garon 1979: 21-28).

10. Jazz musicians associated with bebop are emphatic on the importance of other musicians' appreciation of their music. For characteristic statements see Shapiro and Hentoff 1966: 335-70. 
11. The Southern Christian Leadership Conference was founded by Martin Luther King in 1957. He hoped to apply throughout the South the tactic of nonviolent resistance used successfully in the 1956 Montgomery, Alabama bus boycott. Black Protestant ministers formed most of the leadership. In the 1960s the organization attempted to fight housing discrimination in the North. In this it was less successful and it suffered increasing internal dissension with the radicalization of the civil rights movement.

12. The Student Nonviolent Coordinating Committee was organized after the Greensboro sit-ins. The organization spearheaded black voter organization and education in Mississippi and other Deep South regions which provoked violent reactions. These reactions rapidly radicalized the perspectives of the organization's leadership, one of whom, Stokely Carmichael, articulated the notion of "Black Power." After 1966 SNCC broke with the Gandhian and integrationist visions dominant in the civil rights movement from the 1940s on and became a leading protagonist of black separatism and sanctioned retaliatory violence as a legitimate tactic for the black community.

13. For extensive descriptions of the jazz music of the 1960 s and 1970 s see Gridley 1978 and Collier 1978: 454-93.

14. There were, of course, sympathetic white critics, particularly those writing for the magazine Jazz and Pop. For a characteristic sampling of their work, reprinted from that magazine, see Rivelli and Levin 1979.

15. See, for example, Shepp's statements in "Point of Contact" and "A View from the Inside" in Music '66: Down Beat 11th Yearbook (1966).

16. A compact survey of established jazz musicians' reactions to Ornette Coleman's first New York appearance in 1960 is found in Hentoff 1962: 227-32 \& 239-40. More generally Down Beat's "Blindfold Test" column is a useful source of information on jazz musicians' opinions on each other's work.

17. Although the evidence is scanty it seems quite likely that black jazz was quite well developed before the advent of the mass consumption of culture, if the end of the First World War is taken as an approximate date for the onset of such mass consumption. Although the mechanics of the mass music industry were in place by 1900 , the event which is taken to signal the mass consumption of musical culture in contemporary style is the arrival of white jazz with the Original Dixieland Jazz Band in 1917.

18. Archie Shepp made this point cogently in a June 1968 interview when asked for his definition of the jazz tradition. He responded: "Self-expression. And a certain quality of human dignity despite all obstacles, despite the enslavement of the black man and his oppression. And each of the great players has had so distinctive, so individual a voice. There is only one Bird, one Ben Webster, one Cootie Williams. That's jazz - the uniqueness of the individual" (quoted in Rivelli and Levin 1979: 119). 


\section{REFERENCES}

ALLEN, R.L.

1970: Black Awakening in Capitalist America: An Analytic History. New York: Doubleday.

BERGER, J.

1972: Ways of Seeing. London: British Broadcasting Corporation and Penguin Books.

BERGER, M.

1947: "Jazz: Resistance to the Diffusion of a Culture-Pattern," Journal of Negro History, XXXII/4, 461-94.

COLLIER, J.L.

1978: The Making of Jazz. New York: Delta Books.

COOK, M. and HENDERSON, S.

1969: The Militant Black Writer in Africa and the United States. Madison: University of Wisconsin Press.

GARON, P.

1979: Blues and the Poetic Spirit. New York: Da Capo Press.

GESCHWENDER, J.A.

1978: Racial Stratification in America. Dubuque: William C. Brown. GOODY, J. and WATT, I.

1963: "The Consequences of Literacy," Comparative Studies in Society and History, V/3, 304-45.

GRIDLEY, M.C.

1978: Jazz Styles. Englewood Cliffs, N.J.: Prentice-Hall.

HARRISON, M.

1976: A Jazz Retrospect. Newton Abbot, Devon: David and Charles. HENTOFF, N.

1962: The Jazz Life. London: Peter Davies. HOWE, I.

1967: "The Idea of the Modern," in Howe, I., ed., The idea of the Modern in Literature and the Arts. New York: Horizon Press, 11-40.

JONES, G.S.

1972: "The History of U.S. Imperialism," in Blackburn, R., ed., Ideology in Social Science. London: Fontana, 207-37.

JONES, L.

1963: Blues People. New York: William Morrow.

1967: Black Music. New York: William Morrow. KOFSKY, F.

1970: Black Nationalism and the Revolution in Music. New York: Pathfinder Press.

LASCH, C.

1979: The Culture of Narcissism: American Life in an Age of Diminishing Expectations. New York: Norton. 
LEONARD, $\mathrm{N}$.

1962: Jazz and the White Americans. Chicago: University of Chicago Press.

McLUHAN, M.

1962: The Gutenberg Galaxy. Toronto: University of Toronto Press. OLIVER, $\mathrm{P}$.

1975: "Jazz is Where You Find It: The European Experience of Jazz," in Bigsby, C.W.E., ed., Superculture: American Popular Culture in Europe. Bowling Green, Ohio: Bowling Green University Popular Press, 87-108.

ONG, W.J.

1967: The Presence of the World. New Haven: Yale University Press.

1969: "World as View and World as Event,": American Anthropologist, LXXI/4, 634-67.

ORTEGA y GASSET, J.

1948: The Dehumanization of Art. Princeton: Princeton University Press.

PECK, S.M.

1968: "The Economic Situation of Negro Labor," in Jacobson, J., ed., The Negro and the American Labor Movement. New York: Doubleday, 209-31.

PLEASANTS, $\mathrm{H}$.

1969: Serious Music And all That Jazz. New York: Simon and Schuster.

RIVELLI, P. and LEVIN, R., eds.

1979: Giants of Black Music. New York: Da Capo Press.

ROBERTS, J.S.

1974: Black Music of Two Worlds. New York: William Morrow. ROUT, L.B., Jr.

1971: "Reflections on the Evolution of Post-War Jazz," in Addison, G., ed., The Black Aesthetic. New York: Doubleday, 108-32. SHAPIRO, N. and HENTOFF, N.

1966: Hear Me Talkin' To Ya. New York: Dover Publications. SHEPHERD, J.

1979: "Music and Social Control: An Essay on the Sociology of Musical Knowledge," Catalyst, No. 13, 1-54.

SHEPHERD, J., VIRDEN, P., VULLIAMY, G., and WISHART, T.

1977: Whose Music? A Sociology of Musical Languages. London: Latimer New Dimensions; reprinted New Brunswick, N.J.: Transaction Books, 1980.

SIDRAN, B.

1971: Black Talk, New York: Holt Rhinehart. SPELLMAN, A.B.

1967: Four Lives in the Bebop Business. London: MacGibbon and Kee. 
TIRRO, F.

1967: "The Silent Theme Tradition in Jazz," The Musical Quarterly, LIII/3, 313-34.

WELLBURN, R.

1971: "The Black Aesthetic Imperative," in Addison, G., ed., The Black Aesthetic. New York: Doubleday, 132-49.

WILLIAMS, $\mathrm{M}$.

1973: The Jazz Tradition. New York: New American Library. 